\title{
INDO-PAK HYDROPOLITICS: IMPLICATIONS FOR DISPUTED JAMMU AND KASHMIR
}

\author{
Sardar Jahanzaib \\ MPhil Scholar, Areas Study Center for Africa, North and South America, \\ Quaid-i-Azam University, Islamabad \\ Jahaan12@outlook.com
}

\begin{abstract}
India and Pakistan have been fighting over Kashmir, a contested region that is claimed by both the countries. Competition over waterways and dependence over water assets of Kashmir remains a bone of contention between India and Pakistan. This Research paper discusses the dependence of India and Pakistan over water sources originating from Kashmir. Kashmir, besides emotional attachment also has strategic, economic and political benefits for India and Pakistan. In the twenty first century, traditional concepts of state security have been changed. We have moved from traditional security aspects to non-traditional security aspects. Water is included in one of the non-traditional security aspects. India having all cards in hands is showing its' hegemonic by choking the loose points of Pakistan. Though Indus Water treaty was signed in 1960's to resolve the water issues between the two countries, but still we have not found any direct solution that will resolve the water crisis and provide permanent peace in the region. There is no way forward which will provide a win win situation for India, Pakistan and Kashmir in Indus water treaty. The researcher accounted that Indus Water Treaty has proved successful as far as its' theoretical approach is concerned, but has failed in implementation and practicality. The researcher has used Hourglass model to analyze the Indus Water Treaty and to suggest the way forward that will lead towards a conflict resolution. Mixed methods have been used in the research from secondary sources to analyze water dependence. The research also seeks to analyze Indus water treaty and to explore the prospects for equal division of water resources. The subject matter of the research is Indo-Pak water dependency over water of Kashmir with a focus on how it will contribute towards the socio-economic status of India and Pakistan in the region and also how much dependence on water would affect the regional peace and stability in Kashmir conflict.
\end{abstract}

Keywords: Conflict resolution, Hourglass glass model, Kashmir conflict, India-Pakistan water dependency, Indus water Treaty, Composite Dialogue process.

\section{INTRODUCTION}

Water dependence, as per definition refers to " A use that can be carried out only on, in, or adjacent to water because the use requires access to the water body for water-related transportation, recreation, energy production or source of water" (Water-Dependent Definition, n.d.). We are now in the epoch, a geological epoch in which human action dominates earth's cycles and that is particularly a case with water because water is essential for life. It decides the value and proficiency in water assets, designation dissemination and equalizations of usage between economic, political and strategic environments. As far Kashmir is concerned, for over 73 years, India and Pakistan have been fighting over Kashmir, a contested region that is claimed by both countries. Competition over waterways and dependence over water assets of Kashmir has been a subject of dispute between India and Pakistan. This paper will investigate Indo-Pak water dependency and its' implications on Kashmir. It is based on the hypothesis that resolution of territorial conflict over Kashmir would enable conditions of winwin situation for equal division of water resources.

In 1947, India and Pakistan gained independence from Britain and the two new countries were left to figure out how to divide up the region's natural resources and a very important resource was water of Kashmir i.e., The Indus Basin was somehow considered as the base of dependence of India and Pakistan over Kashmir. The Indus Basin includes rivers which flow from the Himalayas to Arabian sea carrying water through both India and Pakistan. After partition, de-facto borders were drawn and the sources of most of these rivers ended up in India, as Indian occupied Jammu and 
Kashmir was the upper riparian part of Kashmir, so water flows from there to enter Pakistan. Among different undivided assets between India and Pakistan, the permanent solution of water distribution was also left unchecked rather there was only a Standstill Agreement of 1947, which later ended on April 1, 1948. India being upper riparian state started choking the waterways that streamed into Pakistan. The Inter-Dominion Accord of May 4, 1948, expected India to give water to the Pakistan for yearly installments. This also was expected as a temporary measure, with additional discussions to happen in order to arrive at an extremely durable arrangement. In 1954, the World Bank presented a proposition for an answer for the solution of distribution issue. Following six years of talks, Indian Prime Minister Jawaharlal Nehru and Pakistani President Mohammad Ayub Khan signed the Indus Waters Treaty in September, 1960. The treaty however has gone through many ups and downs before agreement and even after that. As in 1948, India stopped the flow of different canals that enter Pakistan (Sashikumar, 2016). This happened later again and as a result, Pakistan pointed out this in front of International community stating that India is stopping the water flow towards different villages of Pakistan. In 1954, world bank came with an idea of resolving this issue, which later got signed by both countries in the 1960's. In 1970's India initiated to build different hydropower projects in Indian occupied Jammu and Kashmir. Again in 1984, Pakistan accused India of building Tulbul barrage on river Jhelum (Bhutta, 2011). In 2007, India started Kishanganga hydroelectric plant (Dawn.com, 2018). Pakistan has taken it as a direct violation of Indus water treaty. From 2008 to 2014, Pakistan has complained time to time over the Indian violations of water treaty, but soon after 2016, India clearly stated that they are working on reviewing the Indus water treaty after Uri attack ("Uri Terror Attack," 2016). So from history, it has seen that water violations of India has created tensions for Pakistan and Indus water treaty is under direct threat ("Uri Terror Attack," 2016) due to clashes between India and Pakistan.

The Treaty gives India power over the waters of the three eastern rivers'; the Beas, Ravi and Sutlej, while authority over the waters of the three western rivers; the Indus, Chenab and Jhelum has given to Pakistan (Bauer, 2020). The Indus Water Treaty was marked between the two states under the protection of the World Bank and upheld by significant world powers. The settlement was done to resolve the water issues between the two nations. During wars (War of 1965, 1971 and Kargil), the treaty remained effective. However, shortage of water resources for both countries are creating questions over the relevance of this treaty, especially from Indian side as they have threatened to violate Indus water's treaty. Narendra Modi once said that "blood and water cannot flow simultaneously" and now India is exploiting water that is flowing towards Pakistan by construction of dams on western side of rivers which raised threats for the survivability of the treaty. The Indian Prime Minister Modi, while addressing the farmers in Indian Punjab vowed to end the treaty unilaterally (Slater, 2019). This is not a favorable situation for Pakistan as it will lead to water shortage. This is one of the fine examples of "Theory of Hegemon", which was developed in 2006 by Mark Zeitoun, defined as "the basin scale hegemony or control over transboundary waters, which is consolidated by one actor. It gives a specific insight into the concept of hydro hegemony (Gupta, 2016,)". Despite having a mutual treaty, both countries are not preserving their water resources. Pakistan is in need to increase its' energy resources and same is the case with India. The researcher will use Hourglass conflict resolution model to analyze Indus water treaty and to propose conflict resolution over Kashmir.

\section{Hourglass Model}

The process of conflict resolution has a lot of complexity. It is a group of interconnected units. The hourglass model can be defined as "The narrowing of political space that characterizes conflict escalation and the widening of political space that characterizes conflict de-escalation." In this procedure, it gives a combination of "Galtung's ideas on conflict and violence with escalation/deescalation phase" to produce the "hourglass" model of conflict resolution responses (Ramsbotham and woodhouse). This model covers conflict transformation, conflict settlement, conflict containment, cultural, structural peacebuilding, peace keeping and follows the flowchart into nine phases which are somehow inter-connected and covers the following steps:

(1) Differences, (2) Contradiction, (3) Polarization, (4) Violence, (5) War, (6) Ceasefire, (7) Agreement, (8) Normalization, and (9) Reconciliation. 

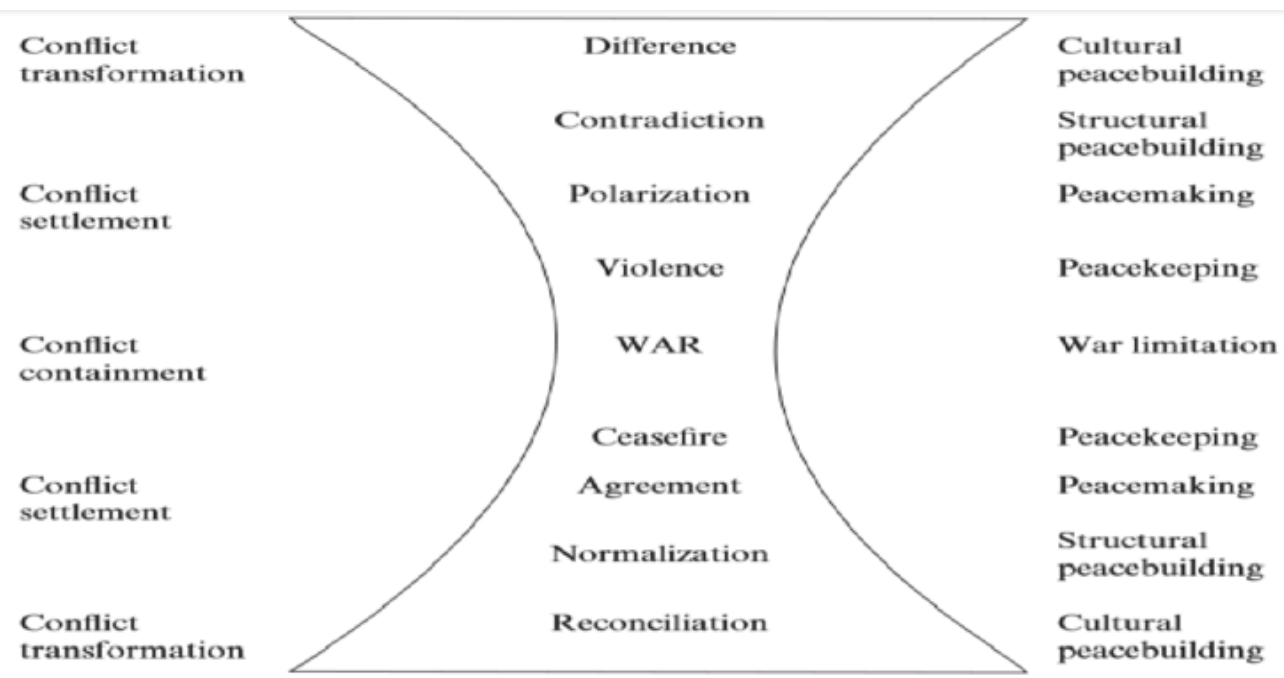

Fig 1. The Hour-Glass model (Ramsbotham et al., 2011, pp. 13-16)

The conflict resolution model follows the above-mentioned escalation and de-escalation phases. In context of water dependency of India and Pakistan, both countries have passed through different phases of this model, but still they are not able to find out the final step. From the history of both nations, we have seen differences among them, and these differences led towards forthcoming phases according to the model. In the Indus water treaty, this model has passed different phases until the agreement phase. This agreement resulted in temporary peace, which did not last for long. Unfortunately, this treaty was not helpful for both states to enter in the phase of normalization and reconciliation rather it again moved towards the phase of differences, which according to researchers was due to the Kashmir conflict between India and Pakistan.

Theoretical application of Kashmir conflict in hour glass model showed that there are certain barriers, which need to be bridged if the conflict wants to achieve all the escalation and de-escalation steps because current agreement (Indus water treaty) failed to bring the phase of normalization at different times.

\section{Nature of Conflict}

The existence of conflict relates to incompatible goals that the concerned parties pursue and develop. To understand a conflict, it is important to pay attention to the origin of conflict, context, developments and life cycle of the conflict. It is also important to pay attention to position, attitude, behaviour, images and values attached to the subject matter that the parties develop for each other as the conflict evolves and new variables added in the equation. The Indo-Pak enmity remains the most enduring unresolved conflict in South Asia. The birth of two states through the decolonization process and the mistrust both parties shared during the freedom movement bred seeds for the conflict. The incompatible territorial goals over Kashmir led to enduring conflict, which has continued for seven decades with wars and low intensity skirmishes. Despite post-conflict phases and occasional peace efforts, the latent conflict continued to persist. The nature of India and Pakistan conflict has changed as conflict has evolved. The conflict between Pakistan and India over a contested territorial claim has contrasting mapping of the conflict between the parties (Bhattacharyya, 2019). The conflict had its origin in the disputed claims over the territory. The seeds of the conflict are rooted in the decolonization process, territorial allocation, the developments that followed the creation of the two states and primarily, the dependence of water on Kashmir.

Maharaja Gulab Singh was given Kashmir by British. He gave 7.5 million rupees to British in order to buy this land of Kashmir (Shaukat, 2017). From 1846 to 1947, the Dogra dynasty ruled Kashmir and the rulers were Hindus, but the majority population was Muslim. When India and Pakistan became independent in 1947, the ruler of Kashmir was Maharaja Hari Singh and he was the descendant of Dogra's, but he did not want to join either India or Pakistan. He wanted Kashmir to be the Switzerland of Asia, Independent and neutral. But there was a party in this kingdom of Kashmir called "National conference". They were struggling against Maharaja for self-rule. They wanted democracy in this kingdom of Kashmir. They wanted the king to be just a constitutional head and 
wanted a constitutional monarchy in Kashmir just like England. Sheikh Abdullah along with other few people have founded this party and they were leading this struggle since 1930, and by the 1947, this national conference was the largest political party in Kashmir. In 1947, Muhammad Ali Jinnah argued that according to the two nations theory, the state of Kashmir with 77\% Muslims should join Pakistan. Maharaja wanted to stay neutral, he did not want to join Pakistan but neither did he want to join India. He signed a standstill agreement with the dominion of Pakistan, means that they will maintain their status-quo until a further deal is made. He was also in talk with India to sign a standstill agreement with India (Schofield, 2002). While these talks were continued, civilians in the Poonch regions raised voices against the state police and army of Maharaja. The army opened fire on them which lead to a rebellion in Poonch region. The tribal Pashtuns also came to support them in their rebellion and were against atrocities against Muslims. As soon as this rebellion started, Maharaja was not able to stop them so he asked Indian Government for help. Indian government asked Maharaja to accede to India and as a result of this pressure, he signed the instrument of accession with India on $26^{\text {th }}$ October 1947 (Schofield, 2002). However, Pakistan rejected this instrument of accession, saying it was signed under duress by an unpopular ruler, not representing the will of the public. Sheikh Abdullah was a good friend of Nehru and he endorsed the accession and was appointed as the head of emergency administration by the Maharaja. India send its' military to repel the attack by Mujahideen and the first India-Pakistan /Kashmir war begins. While this war was going on, a provisional government named "Azad Kashmir" was formed in the western side of Kashmir. The war was cease fired due to snowy weather. India went to UN and United Nations set up commission for India and Pakistan (UNCIP), which tried to resolve the issue but it was unsuccessful in the long run. So a security council resolution was adopted named "Resolution 47 of UNSC". It gave 3 consequential non-binding steps:

- Pakistan should withdraw all nationals and irregulars from Kashmir.

- India should withdraw its' army and keep minimal force in the region

- A plebiscite to ascertain the will of people (Security Council Resolution 47 - UNSCR, n.d.).

But the war continued as both countries stated that if any of them withdraw their army, other country will capture the whole land. The only thing that happened was the ceasefire line in 1948. This line became "Line of Control" which is the de facto border between the region of India and Pakistan and this LOC was officially named after the Shimla agreement 1972. In Shimla agreement, both countries decided that they will bilaterally decide the future of Kashmir, which is still undecided and unresolved.

\section{Kashmir: The water-based conflict}

Disputes over water have been seen in the world on a number of occasions. Increased populations of nations would deliver clashes among countries which are having rich resources in water with the countries with less resources. Upper riparian states that control the progression of water to lower riparian states would utilize this important asset as a discretionary and key strategic instrument to pressurize the lower riparian countries. That is what was developed in 2006 by Mark Zeitoun theory. As indicated by the 2002 United Nations World Water Development Report, "there were 507 conflictive events over water during the previous fifty years. 37 among this involved violence, of which 21 consisted of military acts. Some of the most vociferous enemies around the world have negotiated water agreements [concerning international rivers] or are in the process of doing so" (Sridhar, 2010).

Water of Kashmir originates from Tibetan Plateau. The India and Pakistan rely upon snow which flows in waterways that ascent in the Himalayas. Both rely upon this water for their endurance and food. This water goes through Jammu and Kashmir, which is bone of content between the two nations. This water is famously known as Indus River coming from the Himalayas, which covers the total area of $3200 \mathrm{~km}$ before reaching Arabian Sea. The Indus has five primary tributaries. The Jhelum, the biggest of these, begins in the Valley of Kashmir. The Chenab moves through the Jammu area of the territory of Jammu and Kashmir before entering the Indian province of Punjab. The remaining three; Ravi, Sutlej and Beas move through India's territory of Himachal before entering Indian Punjab. This water is causing clashes between India and Pakistan which are comprising of huge populations and hence are in need of water in large quantity. 
It was due to its' important geo-strategic location that Kashmir got the attention of both India and Pakistan and both are not ready to give up on it. To understand the water-dispute, we need to understand the geography of Kashmir.

\section{Indus water treaty}

The water treaty is the first ever treaty signed between India and Pakistan based on distribution of water. This was signed on September 19, 1960 by then Prime Minister of India Jawaharlal Nehru and President of Pakistan Ayub Khan. The treaty was supervised by World bank (Fact Sheet, n.d.) over river Indus and its five tributaries, which is divided into two groups:

- Eastern Rivers (Sutlej, Beas, Ravi)

- Western Rivers (Jhelum, Chenab, Indus)

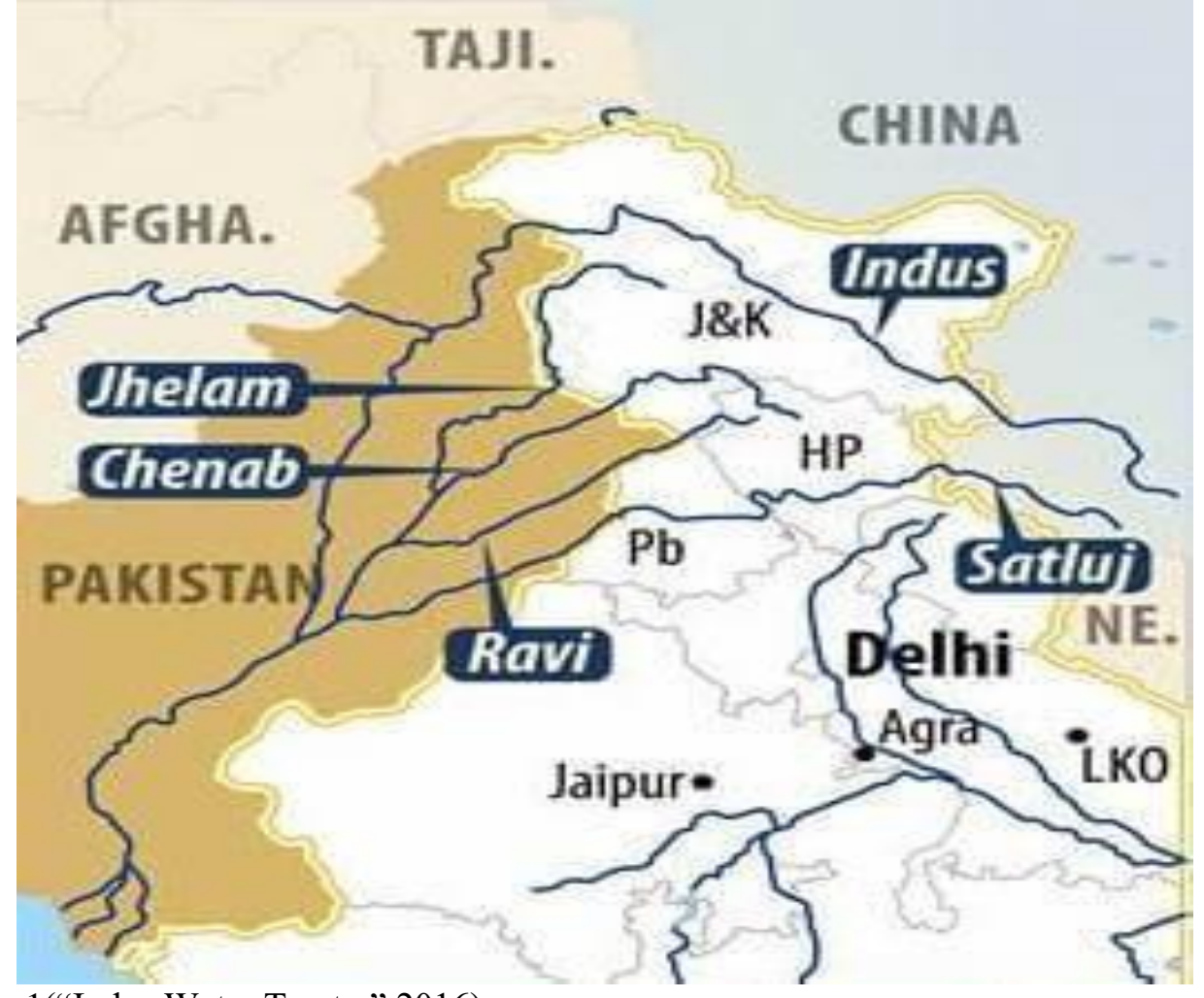

Fig 1(“Indus Water Treaty,” 2016)

According to the Indus water treaty as shown in above figure, the Eastern rivers fared on the Indian side and western rivers fared on the side of Pakistan. According to the treaty, India being an upper riparian state should not control the and restrict the flow of western rivers towards Pakistan. But it did allow India to use this water for "non-consumptive" uses like irrigation, storage and even for electricity. The Indus water treaty has 4 pillars and 12 articles.

- First pillar talks about division of tributaries; eastern and western ones.

- After the treaty, Pakistan got financial assistance, which helps in constructing different hydroelectric projects like Margala and Tarbela.

- Treaty allowed India to use $20 \%$ of western water for domestic purposes on the basis of two conditions. First India is not allowed to store water in constructions of these projects. Secondly, India will not divert water flow of western rivers.

- To ensure the transparency of the treaty, Indus commission have been formed (Bauer, 2020). The commission was settled after this bilateral agreement, which was known as "Permanent Indus Commission" that will help treaty in managing issues and implementation (Bauer, 2020).

\section{Analyzing Indus Water Treaty under Hourglass model}

The Indus water treaty is an initiative for cooperation but in the lens of hourglass model, it was not able to cover up all the nine phases rather from the phase of agreement, it again moved back to 
differences. This, according to the researcher, was due to the conflict of Kashmir and besides strategical, religious and political importance of Kashmir, water is also playing an important role in its' importance for both nations. That is why the cycle of hourglass models could not find permanent normalization

- Differences. and

- Contradiction.

- Polarization

- Violence.

- War

- CeaseFire

- Agreement

- Normalisation

- Reconcilliation. reconciliation.

- Over distribution of water.

- Indo-Pak Positions. (Their claims contradict)

- Events that leds to Conflict.

- Hurting Phase.

- Unconventional.

- Role of worldbank.

- Indus Water Treaty.

- Developement of Trust ( Absent)

- Permanent resolution.

Fig 3.

The reason of this treaty not entering the phase of normalisation was the lack of trust due to which permanent peace never happened. India being an upper riparian have all cards in its' hands. They retreated their hydro-hegemonic behaviour by creating a rhetoric over their water superiority. Pakistan on the other hand, reported this Indian behaviour at international level, which was discussed earlier.

\section{Geography of Kashmir}

It is important to note that Kashmir is a disputed territory divided into three main regions;

- Indian administered Jammu and Kashmir.

- Pakistan administered Azad Kashmir.

- Ladakh.

Fig. 1 clearly shows how Kashmir is divided into three different areas.

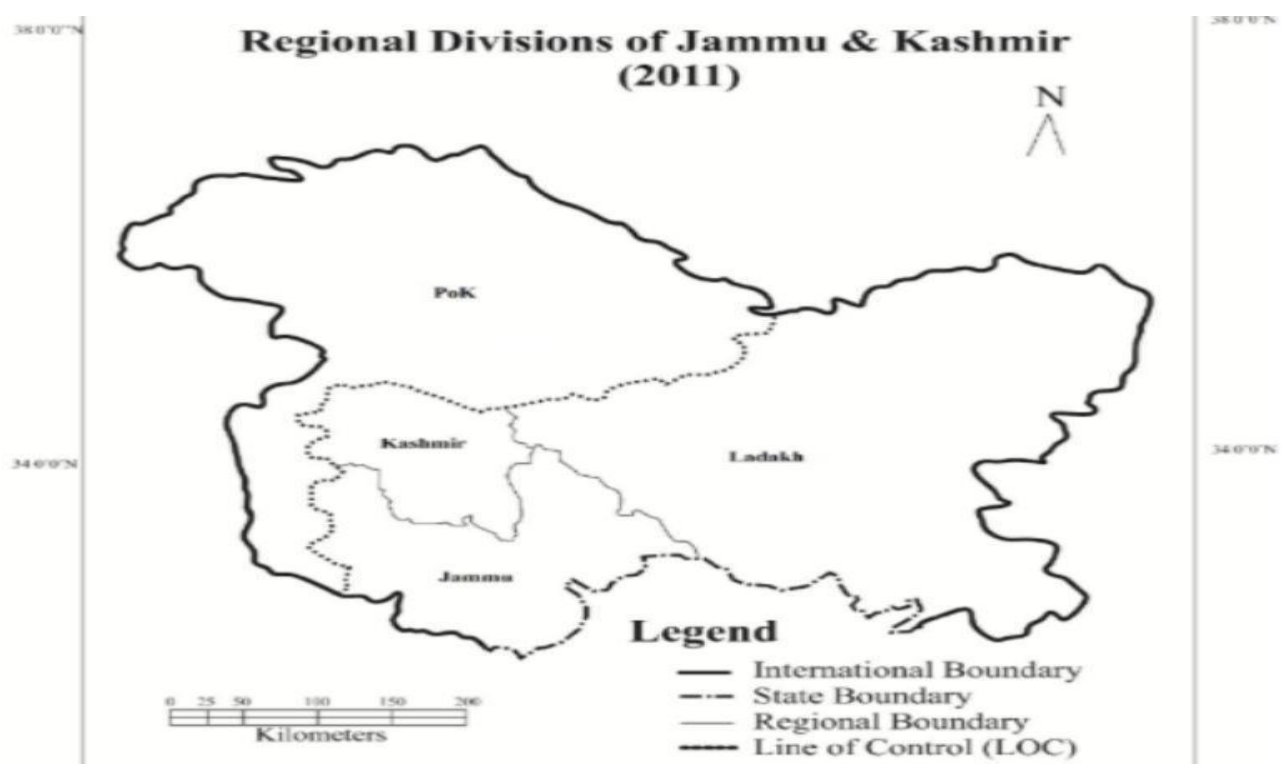

Fig 4. (Ahmed, 2018, pp. 1-10)

This place derived its' name from Sanskrit language, which means "desiccated water". "Ka" means the water and "Shamir" means to desiccate (Chonker, 2018). Kashmir lies in north-western region, with complex Himalayan ranges marked with snow. It is situated between Pir Panjal Range (of lesser Himalayan region) and Zanskar range with an area of about 15220 sq. km. Jammu (Indian occupied Kashmir) is situated in south-west along Pakistan border to Pir Panjal Range, it is Hindu- 
majority area (Kashmiri Pandit Network (KPN): Home, n.d.). The "Jhelum River" is one of the main waterways of Kashmir. It originates from a spring called Verinag that is situated at the foot of Pir Panjal range of Lesser Himalayas. It flows at about $25.6 \mathrm{~km}$ from Khanabal to Wular lake, from where it flows out to Baramulla and finally enters the boundary of Pakistan. Srinagar is suited to either side of Jhelum river. There are few other rivers that flows through the regions such as Indus and Chenab. The upper valley of Jhelum (the Vale) encircles mountains and this area mostly belongs to Azad Kashmir Pakistan. There are many other "low-lying valleys" in the region such as the "Poonch Valley, Tawi Valley, Sind Valley, Chenab Valley, and the Liddar Valley" but the main among them is the "Kashmir Valley"(Kashmiri Pandit Network (KPN): Home, n.d.).

Kashmir has more physical proximity with Pakistan; the upper valley of Jhelum and the southwestern parts of the river flows directly into the Indus in Pakistan. There is an extension of the Pir Panjal Range between India and the south-western lowlands and hills of Kashmir. The Vale and the southwest region of Kashmir are most densely populated and are closely linked to Pakistan.

The Indus River, on which India and Pakistan are highly independent, have two of its tributaries originating in disputed Kashmir. It has a basin area of about $1.12 \times 10^{\wedge} 6 \mathrm{~km} 2$ from which Pakistan gets 47\%, India 39\%, China 8\%, and Afghanistan 6\% of water (Kalair et al., 2019, pp. 15-18). The Jhelum river flows from the valley of Kashmir, and Chenab flows from Jammu Kashmir and finally enters the Indian State of Punjab. Fig. 2 shows that rivers flowing from Kashmir and entering Pakistan to join the Indus River that finally flows to Arabian Sea.

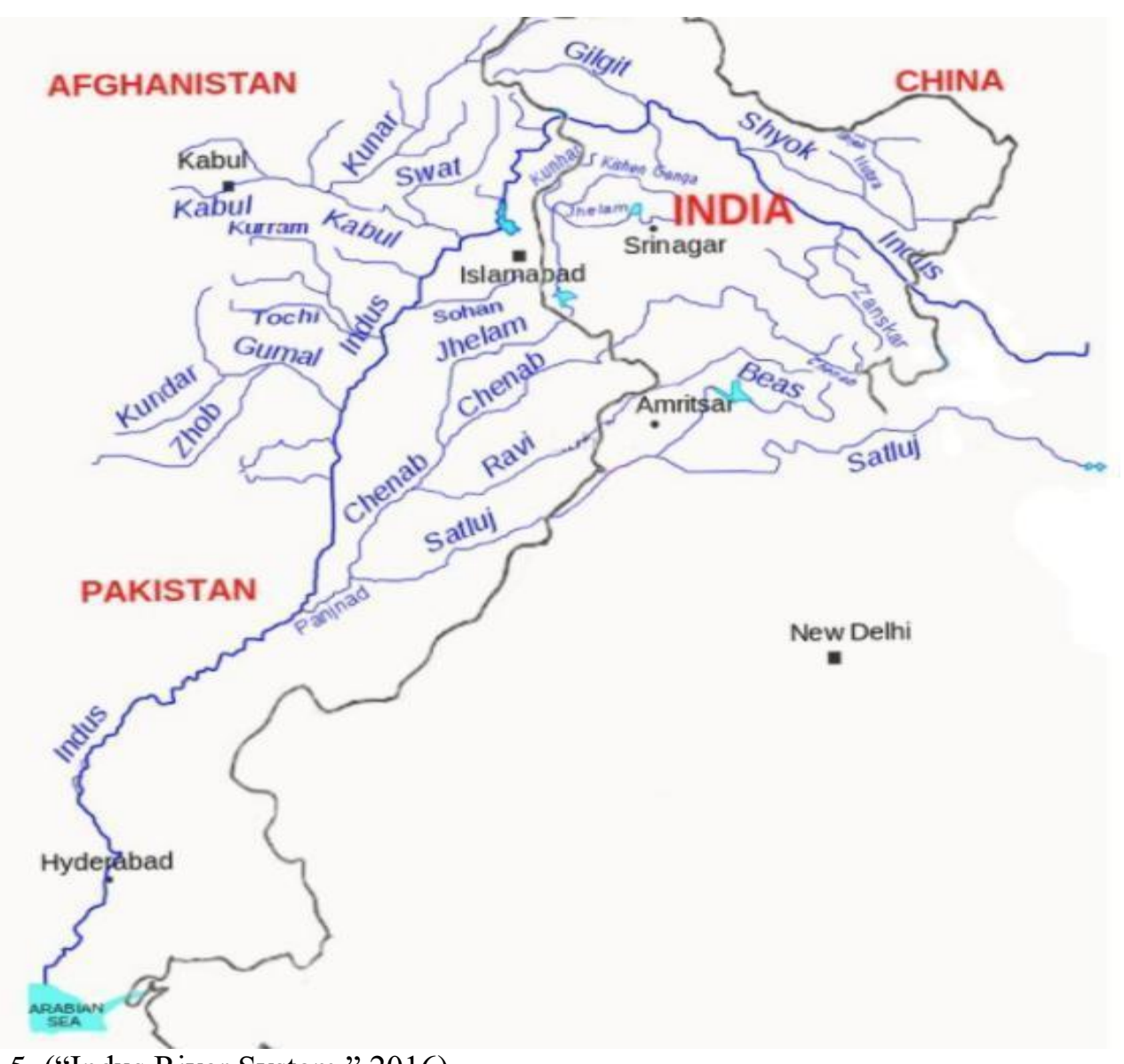

Fig 5. (“Indus River System,” 2016)

Water dependence is a conflictual area for many decades. The reasons include that both India and Pakistan are economically dependent on water resources of Kashmir and neither of them can compromise on it. Therefore, it is important to see how these two states are dependent on Kashmir's water.

\section{Position of Pakistan}


The Indus is a water continuing network in India and Pakistan. In Pakistan, it is the main water stream that nourishes more than 92 percent of the land which is parched or semi-dry. Given that, the majority of Pakistan's populace is working in the areas of horticultural and agriculture. So, they are in a dire need of the water to fulfill their needs. The fact is that Pakistan is totally dependent on the Indus flow due to its' geographical location. India has advantage for being at the upper riparian region and from there, all 5 of main tributaries flow into Pakistan. John Briscoe, a professor at Harvard University, recognised Pakistan's vulnerable position in the following words: This is a very uneven playing field. The regional hegemon is the upper riparian and has all the cards in its hands ("On Pakistan-India Water Dispute," n.d.).

Pakistan is wholly dependent on the Indus river and India enjoys a strategic advantageous position by having control of the upper riparian of Indus system which makes it able to control the flow of water. Both countries have water issues, but Pakistan is "extremely high-stressed" when it comes to water scarcity ("What Kashmir's Looming Water Crisis Means for India-Pakistan Relations," n.d.). The reason Pakistan wants to control Kashmir is to have development in hydroelectric power generation and to secure its' water resources that fulfill irrigation purposes in Punjab and Sindh. From the waters of the Indus system, only 20-45\% is used in irrigation plans (Mayfield, 1955). Among the 31 canals in Punjab's, only one or two receive water from Kashmir. Despite such facts, emphasis on controlling Kashmir is laid when it comes to irrigation issues.

Pakistan constructed one of the seventh largest dams of the world on river Jhelum; "Mangla Dam". This dam is constructed in Mirpur District of Pakistan, Azad Kashmir and serves in multipurposes way. It has a capacity to generate around $1500 \mathrm{MW}$ power and can be used for irrigation purposes and a part of the Indus Basin project. Pakistan had further constructed barrages (smaller dams) to use water coming from Kashmir for irrigation purposes. "Marala Barrage" is constructed on River Chenab that divert water for irrigation purposes (Mayfield, 1955). Furthermore, Pakistan constructed "Rasul Barrage", "Qadirabad Barrage" and Trimmu Barrage over the water that come from Kashmir to utilize it in agriculture sector (Mayfield, 1955). But Pakistan has been slow in completion of many of its' projects that can lead to water scarcity.

So, Pakistan is in no position to lose its hold over Kashmir as Pakistan will face immense shortage of water, which will affect the economy of Pakistan. Besides agricultural dependence, there are others dams which helps in the supply of water for irrigation. Moreover, this water is being used for the purpose of drinking and as it has the sweet taste and a bulk of fishes in it are used as a food. so, besides emotional attachment, Kashmir serves as a tool for the economic, political and strategic development for Pakistan as well.

\section{Position of India}

Similarly, in case of India, it is an important waterway that supports the area of northwest: Punjab, Haryana and Rajasthan (water lacking regions). Punjab delivers more than $20 \%$ of India's wheat and is known as the "bread bin" of the Republic of India. India water dependence on Kashmir is the same as Pakistan. India is one of the major exporters of wheat, rice and other horticultural products. Same as Pakistan, India's majority population are living in villages and this majority population earns through agriculture. So, water plays an important role for them. Similarly, Indus Basin covers the area of Punjab and to a major extent Rajasthan as well. The water covers the area of Jammu and Kashmir, Himachal Pradesh, Punjab, Rajasthan, Haryana and the Union territory of Chandigarh (Tabbasum, 2013). The flow of water will be discussed as follows:

Table No.1 Agricultural land dependency on water of Kashmir

\begin{tabular}{|l|l|}
\hline State & Drainage area $(\mathbf{S q} \cdot \mathbf{k m})$ \\
\hline Jammu and Kashmir & 193,762 \\
\hline Himachal Pradesh & 51,356 \\
\hline Punjab & 50,304 \\
\hline Rajasthan & 15,814 \\
\hline Haryana & 9,939 \\
\hline Chandigarh & 114 \\
\hline Total & 321,289 \\
\hline
\end{tabular}


This is the total area which is used for agricultural purposes and it shows Indian dependence on rivers of Kashmir. India is a home to a large population of about 1.3 billion people, so it must find ways to feed these people enough ("What Kashmir's Looming Water Crisis Means for India-Pakistan Relations," n.d.) Along with agriculture, it needs water for many other purposes such as hydroelectricity. Despite signing the Indus Water Treaty, India has always turned the game to its' side. India always has plans for constructions of dams over the waters from Kashmir to gain maximum profits.

The "Baglihar Dam" is a point of dispute between Pakistan and India. India decided to construct a dam on river Chenab (tributary of Indus River), which was a $450 \mathrm{MW}$ hydroelectricity plant (The Baglihar Dispute - International Water Power, 2006). Pakistan objected that the construction of the dam in terms of its' design, the pondage and the spillways were all against the Indus Water Treaty. When the two countries could not resolve the matter, the World Bank appointed Professor Raymond Lafitte to resolve the matter. His final decision came on $12^{\text {th }}$ February 2007, where he only shows concern over Pakistan's minor objections and gloss over the major ones and India completed the second stage of dam construction in 2015-16.

Another construction of a dam that raises concerns of Pakistan is the "Kishanganga Dam". This dam holds great potential for India when it comes to hydroelectricity production generating of 1,713 million units of electricity per year and for irrigation purposes (Iqbal, 2018). This dam diverted water from Kishanganga river before it entered Pakistan Azad Kashmir region. In 2018, Prime Minister Modi inaugurated the project. Pakistan seek World Bank arbitration but failed to resolve the issue.

India ranks $5^{\text {th }}$ in the world ranking when it comes to the exploitation of hydro-potential. Keeping in view of its ever-increasing requirement, India called for construction of another dam on Chenab, "Bursar hydroelectric project". It has the capacity of 1,020 MW of electricity, greatly reducing the water flow to Pakistan. India also plans projects i.e, Pakal Dul, Dul Hasti, Rattle, Sawalkot and Salal (Iqbal, 2018).

India has built potential to use this water for the agriculture sector. Recent irrigation development took place in East Punjab will use water that goes to Pakistan and the diversions built on River Chenab. Even within Jammu, India had started economic development. To an agrarian state, agriculture related reforms won many hearts and India followed this same policy and it constructed "Sind dam" near Srinagar, a multi-purpose dam to meet the demands (Mayfield, 1955). India had always enjoyed the advantage of controlling the upper riparian of the Indus river and its tributaries and had often used water as a weapon against Pakistan. It often not only threatened Pakistan but also stopped the water from flowing towards Pakistan. Pakistan being an agrarian country is highly affected by such acts. David E. Lilienthal in one of his article truly explained the picture by saying, ""No army could devastate a land so thoroughly as could India by shutting off Pakistan's water supply (Mayfield, 1955).

\section{Composite Dialogue Process}

Composite Dialogue Process was started between Islamabad and New Dehli back in December 1985, when Pakistan's President Zia-ul-Haq visited India on his way back from SAARC summit from Dhaka with an aim to resolve their issues and differences bilaterally. Again in 1997, Indian Prime Minister Inder Kumar Gujral and Pakistani Prime Minister Nawaz Sharif restarted this dialogue process and agreed to look into eight different issue which are "(a). Peace and security, (b). Jammu and Kashmir, (c). Siachen, Wullar barrage, (d). Tulbul navigation project, (e). Sir Creek, (f). Economic and commercial cooperation, (g). Terrorism and drug trafficking, and (h). Exchange of goods."

This went well in start but later in the 1990's, in a meeting related to Jammu and Kashmir, Indian delegates were of view that there is nothing to talk about on Kashmir. The dialogue again faced some pauses due to different opinions and then again in 1998, Vajpayee and Nawaz Sharif started to work on a composite dialogue process but this later faced the Kargil conflict and Oonce again dialogue over this issue has stopped. In 2001, Indian Prime Minister Vajpayee invited President General Pervez Musharraf which led to bilateral meetings at sideline of "12th SAARC summit", held at Islamabad in 2004. Again the two leaders agreed to work on composite dialogue process mutually. The process of this bilateral talks faced resistance as a result of the incident of the Lal Masjid in 2007 
which forced President Musharraf to take serious steps. This was followed by bombing on the Samjhauta Express Train in India on February 18, 2007. The Mumbai attack of November 26, 2008 ended bilateral relations and stopped the composite dialogue process. On 5th August 2019, Indian Government abrogated Article 370 of their Constitution and the bifurcation of the state of Jammu and Kashmir into two union territories which has stolen the special status from Jammu and Kashmir. This again affected the relations of both states to a greater extent that Pakistan is continuously objecting this act as a direct threat to freedom of people of Kashmir and censuring the restrictions imposed on Kashmir to snatch their freedom and liberties.

\section{WAY FORWARD}

The only way forward on water issue is the conflict resolution of Kashmir. It can serve as an only way to help India-Pakistan to get desired results from the water of Kashmir and this cooperation will bring development in Kashmir as well. Moreover, this resolution could help them to enter the phase of normalization and reconciliation. For the successful conflict resolution, both countries should reinitiate the "Composite Dialogue process" for successful conflict resolution. The researcher suggests that in order to create equal opportunity for India, Pakistan and Kashmir over water dependence, conflict resolution can play an important part to get the final phase of normalization and reconciliation. Thia can only be achieved when both countries will mutually agree upon reestablishing the composite dialogue process, which will help them to gain enough resources and to settle their long-term enmity.

\section{CONCLUSION}

Water is of prime importance as far as life is concerned and besides eco-system, it has strategic, economic and political advantages in global politics. India and Pakistan, being nuclear armed countries have a long historical rivalry. Both countries share common similarities, which includes history, civilization and different natural resources. Since traditional concepts of state security have been changed in the 21 st century. It has moved from traditional security aspects to nontraditional security aspects. Water is included in one of the non-traditional security aspects. The Indus water treaty is the best example as far as transboundary water Issues are concerned. Trans- boundary water issues can lead into 2 different paradigms:

1. This will lead towards Water war

2. This will lead towards Water co-operation

Currently, tensions are rising between India and Pakistan over water of Kashmir. This threat of shared natural resources is now showing detrimental effects. Indus water treaty was proven to be effective only before India started constructions of dams on disputed water resources. The major construction was on the Chenab river, which includes Baglihar dam, Pakal dul dam, sawalkot dam, Dul hasti dam. On Jhelum river, India is constructing Kishanganga dam, Uri I dam and Uri II dam. Nimoo-bazgo project is constructed on Indus tributary. This dam construction will give leverage to India to over flowing water towards Pakistan for up to 20 to 25 days in the dry season. In the 1980's, another important discourse came in international relation related to water which is that the next world war is going to be on water. The importance of emerging water challenges was clearly mentioned by "world economic forum" in global risk index, which was published in 2015. Similarly, the water dependence of India and Pakistan over Kashmir is permanent bone of content and this conflict is playing some hidden roles in initiating different clashes between the two. However, it does not result in any direct wars, but it does show detrimental effects. Since both countries are facing enormous increases in their population and this increase needs over water to fulfil their requirements. India with a total population of 1.353 billion and Pakistan with a total population of 212.2 million (including Kashmir) needs such solution that results in win-win situation for both countries and for Kashmir as well. By 2050, both nations will face water scarcity if they continue with their poor water governance and management.

For Pakistan it is important as water is necessary for the regulation of its' economic growth and to fulfill its' population needs. If the issue would resolve India can gain direct access to Central Asian regions from Gwadar and Chabahar to improve their trade through a shorter route. It can help India to be a part of CPEC, which will be equally beneficial for them in order to gain regional stability against China. Above all, India is having 7 million of army inside Kashmir and this huge number puts 
a lot of pressure over the economy of the state as well. With a total military budget of $\$ 71.1$ billion, India is spending much more on its' military than any other country in south Asia. So, resolution of conflict will automatically lower down this huge burden from them. India and Pakistan can start regional hydro-diplomacy over SAARC and this will be equally beneficial for them.

\section{REFERENCES}

Ahmed, I. (2018). Geographic profile of Jammu and Kashmir state, location, physiographic division, economic, society, etc.

Bauer, P. (2020). Indus Waters Treaty | History, Provisions, \& Facts. In Encyclopedia Britannica. Retrieved from: https://www.britannica.com/event/Indus-Waters-Treaty

Bhattacharyya, S. (2019, September 21). Jammu and Kashmir: The view from India. Retrieved from: https://www.trtworld.com/opinion/jammu-and-kashmir-the-view-from-india-29991

Bhutta, Z. (2011, May 13). Pakistan-India water disputes: No headway in Wullar Barrage negotiations. The Express Tribune. Retrieved from: http://tribune.com.pk/story/167610/pakistan-indiawater-disputes-no-headway-in-wullar-barrage-negotiations

Chonker, A. (2018, March 28). A Peep into Kashmir History-Prehistoric to Pre-Independence Times. Indian Defence Review. Retrieved from: http://www.indiandefencereview.com/a-peep-intokashmir-history-prehistoric-to-pre-independence-times/

Dawn. (2018, May 20). Pakistan to voice concerns over India's Kishanganga dam with World Bank on Monday. DAWN. Retrieved from: https://www.dawn.com/news/1408901

World Bank. (n.d). Fact Sheet: The Indus Waters Treaty 1960 and the role of the World Bank. Retrieved from: https://www.worldbank.org/en/region/sar/brief/fact-sheet-the-indus-waterstreaty-1960-and-the-world-bank

Gupta, J. (2016). The Watercourses Convention, Hydro-hegemony and Transboundary Water Issues. The International Spectator, 51(3), 118-131.

Indus River System: Jhelum, Chenab, Ravi, Beas \& Satluj. (2016, January 19). PMF IAS. Retrieved from: https://www.pmfias.com/indus-river-system-jhelum-chenab-ravi-beas-satluj/

Indus Water Treaty: Everything you need to know. (2016, October 6). ClearIAS. Retrieved from: https://www.clearias.com/indus-water-treaty/

Iqbal, A. (2018, May 20). Explainer: What is the Kishanganga water dispute. DAWN.

Kalair, A. R., Abas, N., Ul Hasan, Q., Kalair, E., Kalair, A., \& Khan, N. (2019). Water, energy and food nexus of Indus Water Treaty: Water governance. Water-Energy Nexus, 2(1), 10-24.

Kashmiri Pandit Network (KPN): Home. (n.d.). Retrieved from: http://www.ikashmir.net/index.html

Mayfield, R. C. (1955). A Geographic Study of the Kashmir Issue. Geographical Review, 45(2), 181196.

On Pakistan-India Water Dispute. (n.d.). Jahangir's World Times. Retrieved from: http://jworldtimes.com/pakistan-affairs/on-pakistan-india-water-dispute/

Ramsbotham, O., Miall, H., \& Woodhouse, T. (2011). Contemporary Conflict Resolution. Polity.

Sashikumar, V. (2016, September 30). Why the Indus Waters Treaty has stood the test of time. Herald.

Schofield, V. (2002, January 16). Kashmir: The origins of the dispute. Retrieved from: http://news.bbc.co.uk/2/hi/south_asia/1762146.stm

Security Council Resolution 47-UNSCR. (n.d.). United Nations Security Council Resolutions. Retrieved August 10, 2021, from http://unscr.com/en/resolutions/47

Shaukat, R. (2017, March 15). The day Kashmir was sold. The Nation. https://nation.com.pk/16-Mar2017/the-day-kashmir-was-sold

Slater, J. (2019, February 22). India wants to use water as a weapon against Pakistan. A 59-year-old treaty stands in the way. Washington Post.

Retrived from: https://www.washingtonpost.com/world/2019/02/22/indias-threats-pakistanoffer-hint-future-water-wars/

Sridhar, S. (2010, May 11). Kashmir and Water: Conflict and Cooperation. IDEALS. Retrieved from: https://www.ideals.illinois.edu/handle/2142/15473

Tabbasum, S. (2013, August 27). Water adds to the importance of Kashmir. Institute of Stategic Studies Islamabad. Retrieved from: https://issi.org.pk/water-adds-to-the-importance-ofkashmir/ 
The Baglihar dispute-International Water Power. Retrieved from: https://www.waterpowermagazine.com/news/newsthe-baglihar-dispute

Water-dependent Definition: 162 Samples. (n.d.). Law Insider. Retrieved from: https://www.lawinsider.com/dictionary/water-dependent

What Kashmir's Looming Water Crisis Means for India-Pakistan Relations. (n.d.). The National Bureau of Asian Research (NBR). Retrieved from: https://www.nbr.org/publication/whatkashmirs-looming-water-crisis-means-for-india-pakistan-relations/ 